\title{
Sejarah Bangsa Israel Awal dalam Perspektif Tafsir Sejarah Teologi Alkitabiah dan Arkeologi Biblikal
}

\author{
Koes Adiwidjajanto \\ Universitas Islam Negeri (UIN) Sunan Ampel, Surabaya \\ k_adiwidjajanto@yahoo.com
}

\begin{abstract}
This article is about history of ancient Israel in biblical era and how the sacred scripture introduces information of the ancient people. We have to know how to read the scriptures. They demand an imaginative effort, as Karen Armstrong said, that can sometimes be as perplexing and painful job. The true meaning of scriptures can never be wholly comprised in a literal reading of the text, since that text points beyond itself to reality that cannot be totally grasp. Our academic world cultivates us to look for the words between the lines. We expect a text to express its idea as clearly as possible. In a philosophical or historical work, we will often judge writers by the precision and consistency of their arguments. There are Jews and Christians who have come to apply the same standards to Bible. Some, for example, have argued that the chapters of Genesis and Chronicles are factual accounts on history of ancient Israel people. But what we need to the Bible does not present its truths to us in this way. This article presents two main methods to understand the historical contains of the biblical text: historical interpretation and biblical archaeology to know at some profound level the sacred history of biblical Israelites people.
\end{abstract}

Keywords: History of Ancient Israel, Historical Interpretation, Biblical Archaeology. 


\section{Pendahuluan}

Bangsa yang mendiami lokasi geografis letak terjadinya berbagai peristiwa penting pada zaman-zaman kuno dalam tulisan ini adalah kawasan yang pada saat $J A$ (Jewish Antiquities, Flvius Josephus) dinamakan Judea. Tanah ini, dalam Perjanjian Lama, ditegaskan sebagai kawasan yang dihuni oleh keturunan Kana'an, yang menurunkan suku bangsa Sidon, Heth, Jebus, Amorites, Gigashite, Hivites dan lima suku bangsa lainnya. Mereka adalah bangsa yang menyebar dari Sidon ke Gerar, sampai sejauh Gaza, ke arah kota Sodom. Gumorah, Adman dan Zeboim sampai sejauh Lasha. Secara kebangsaan, famili dan bahasa mereka adalah keturunan Ham, putra Nuh. Menurut Josephus Flavius, dari bangsa Kana'an inilah kawasan itu dinamakan dengan tanah Kana'an putra Mesraim. Keturunan-keturunan Mesraim adalah mereka yang mendiami dan menguasai kawasan dari Gaza sampai Mesir, tanah yang umumnya disebut dengan letak geografis—-tanah yang dikuasai olehPhilistine. ${ }^{1}$

Memperdalam kajian tentang sejarah Yudaisme sangat kompleks karena sejumlah orang Yahudi akan menampik bahwa menjadi Yahudi sama halnya dengan menjadi religius. Mengkaji Yudaisme akan melibatkan sesuatu yang religius, baik secara individual maupun kolektif, dan itu merupakan persoalan yang menarik bagi antropolog, sosiolog, psikolog dan, terutama, bagi sejarawan. ${ }^{2}$ Kita tidak bisa semata memandang Yudaisme sebagai agama yang hidup (living religion). Apalagi jika kita—sebagai seorang Muslim—menyaksikan kekejaman-kekejaman yang mereka lakukan di Jalur Gaza. Perbuatan mereka yang kita saksikan di televisi setidaknya sangat jauh dari gambaran umat beragama. Definisi sebagai penganut Yudaisme akan jauh panggang dari api jika seseorang dari mereka ditanya tentang 'penciptaan'. Ia akan menjawab bukan dengan konsep dari legenda Kitab Kejadian (Genesis) atau yang tersurat dari Talmudik, melainkan menjawab melalui ilmu fisika dan sains. ${ }^{3}$

\footnotetext{
1 Flavius Josephus, Jewish Antiquities, translated by William Whilston, (Herfordshire: Wordswoth classic, 2006), chapter 6:136, h. 19.

${ }^{2}$ Jacob Neusner, the Way of Torab: An Introduction to Judaism, 3rd edition (Belmont, [Calif]: Wadsworth, Inc., 1979), 4.

${ }^{3}$ Ibid., 5.
} 
Kita sejatinya memisahkan antara "Jemaat Yahudi" (mereka yang lahir dari ibu seorang Yahudi atau konversi ke Yahudi) dengan seorang "Yudaist" (seorang yang mempraktikkan dan mengimani Torah). Tegasnya, keyahudian terkait dengan konteks dan latar belakang kultural. Dengan kata lain, terkait dengan konsep tentang ekologi sensitif, mengingat sejarah orang Israel dan Yudaisme yang sama-sama terkait dengan Tanah Suci (Holy Land) — yang disebut sebagai Tanah Israel (Erets Yisrae) dan kini menjelma menjadi negara Israel. Padahal sejak abad ke-2 Masehi mayoritas orang Israel berada di luar Israel. ${ }^{4}$ Kelompok Yahudi adalah sebagian kecil orang yang masuk dalam kategori ini. Bagaimana sekelompok umat dikategorikan dalam golongan ini secara berbeda dari yang lain merupakan persoalan yang sangat menarik-bukan karena kesamaan bahasa, kultur maupun tradisi ekonomi. Kesamaan mereka terletak pada dasar sejarah periode damai, ketenangan dan periode panjang peperangan, penindasan, represi dan tragedi: latar belakang sejarah sekaligus teologis. ${ }^{5}$

Artikel ini hendak melacak sejarah Yudaisme dari sudut pandang sejarah janji antara Allah dan Abraham beserta anak cucunya, Yaqub (atau yang disebut dengan Israel), Musa dan Daud. Sejarah Israel adalah hikayat tentang Allah yang berkehendak menyelamatkan umat Israel dari Mesir, sehingga sebagai umat pilihan Allah mereka tunduk kepada-Nya sebagai bentuk perjanjian dengan-Nya. ${ }^{6}$ Artikel ini menggunakan peristiwa-peristiwa Alkitab untuk upaya merekonstruksi sejarah. Alkitab diperlakukan bukan sebagai sumber sejarah melainkan sebagai alat di antara berbagai alat yang lain dalam merekonstruksi sejarah. Kajian ini berkaitan dengan interpretasi Alkitabiah. ${ }^{7}$

Tegasnya, artikel ini dibatasi sebagai tulisan tentang sejarah keselamatan yang berkaitan dengan teologia biblical. Ia diharapkan bisa membantu kita menjelaskan bahwa Allah berkarya dengan cara "terlibat langsung dalam proses di alam ini, melalui umat Israel dengan

\footnotetext{
${ }^{4}$ Ibid., 4-5.

5 Ibid., 5-6.

${ }^{6}$ Neusner, The Way of Torah, 8-9.

${ }^{7}$ John Rogerson, Studi Perjanjian Lama Bagi Pemula (Jakarta: BPK Gunung Mulia, 1993), 39.
} 
menyelamatkan mereka dari Mesir dan memberikan mereka Tanah Perjanjian sebagai negeri mereka." Itulah maksud dari sejarah penyelamatan. ${ }^{8}$ Hal inilah yang mendorong saya membahas sejarah Israel melalui metode yang dikembangkan oleh Mircea Eliade, yakni gagasan tentang Yahweh yang tidak memanifestasikan dirinya dalam waktu kosmik (sebagaimana dewa-dewa lain dalam konsep kepercayaan kuno). Yahweh memanifestasikan diri pada waktu historis. Dengan kata lain, Yahweh yang telah melakukan intervensi personal dalam sejarah dan hanya memiliki arti mendalam bagi umat-Nya-sebagai bangsa yang terpilih. Oleh karena itu, peristiwa historis dalam konteks kajian ini adalah sebuah teofani. ${ }^{9}$ Sejarah Alkitabiah dari teks-teks Biblikal ini adalah sejarah keselamatan yang memiliki arti sakral (sacred history).

\section{Sejarah Israel dalam Sumber-sumber Alkitabiah dan Arkeologi Biblikal}

Bagian-bagian pertama Kitab Kejadian (Genesis) yang membangun teks-teks tentang asal-usul patriakh (bapak-bapak leluhur) Israel tidak dimaksudkan sebagai catatan kesejarahan, tetapi lebih sebagai perenungan tentang hakikat kehidupan. Syair-syair dari salah satu sumber $\mathrm{P}$ (Priestly, atau Imamat) dari Perjanjian lama pada hakikatnya berdasarkan imajinasi. Tidak ada saksi mata tentang bagaimana Tuhan berkarya. Tidak ada yang tahu bagaimana sesungguhnya Allah berpikir maupun berfirman. Beberapa orang Yahudi maupun Kristen-dalam upaya menjelaskan bagaimana para penulis Alkitab itu menghadirkan informasi-bersikukuh bahwa Tuhan sendirilah yang mendiktekan teksteks Alkitab itu kepada Musa.

Bagaimanapun, para editor Alkitab tidak tertarik dengan kemungkinan bahwa secara literer peristiwa itu bisa diterima sebagai fakta kejadian. Mereka langsung mengalihkan kisah literer itu dengan sumber dari $\mathrm{P}$ karena perbedaannya yang signifikan dengan ciri umum, mulai dari ayat 2:4 dalam Kitab Kejadian yang ditulis oleh pengarang yang oleh sejarawan disebut dengan sumber J (karena sejak itu Tuhan

${ }^{8}$ Ibid., 63, 105.

${ }^{9}$ Mircea Eliade, Sakral dan Profan, (Yogyakarta: Fajar Pustaka Baru, 2002), 112. 
lebih sering dipanggil dengan Yahweh, biasanya dianglisisasi dengan kata Jehovah: 'J'). Di dalam PL versi NRSV, kata itu diganti dengan penamaan the lord. Sumber yang lain dalam Kitab Kejadian (Genesis) menyebutnya dengan ' $\mathrm{E}$ ' (karena nama tuhan disebut dengan panggilan Elohim) yang berbeda dengan sumber ' $\mathrm{J}$ ' yang tidak terganggu secara etis dengan perilaku para patriak $h .{ }^{10}$

Sebuah teks dinilai bersifat historis minimal karena dua hal: (1) teks itu berkaitan dengan sejarah, (2) teks tersebut memiliki sejarahnya sendiri. Ada dua unsur yang mesti dibedakan di sini, yakni "sejarah di dalam teks" dan "sejarah dari teks". Poin pertama adalah tentang sejarah yang dituturkan oleh teks, sementara yang kedua adalah sejarah teks itu sendiri. Dengan kata lain, teks PL ditempatkan sebagai jendela dimana kita bisa memandang suatu periode sejarah. Bila dipandang secara kritis, teks bisa memberikan gambaran tentang kondisi keagamaan, sosial dan politik dari sejumlah periode sejarah. Sedangkan sejarah teks tidak terkait dengan apa yang dituturkan oleh teks-tentang kapan, siapa dan untuk siapa teks itu sendiri ditulis. ${ }^{11}$

Studi kritis historis terhadap tulisan-tulisan Alkitabiah didasarkan dari asumsi-asumsi tentang titik tekan dari peristiwa yang dibentangkan oleh penulisnya, sumber-sumber informasi, dan sebagainya. Seorang yang melakukan studi kritis terhadap Alkitab seharusnya fokus pada situasi yang digambarkan oleh teks dan situasi yang melahirkan teks. Situasi yang pertama lebih fokus pada persoalan kesejarahan dalam Alkitab. Situasi-situasi kebudayaan dan kesejarahan yang melahirkan tulisan Alkitabiah perlu diperhatikan pula oleh penafsir. Ini membantu

\footnotetext{
${ }^{10}$ Contoh: LAI (lembaga Alkitab Indonesia Cukup menyebutnya dengan 'Tuhan', lihat: umpamanya tentang panggilan 'Tuhan' (the Lord) kepada Abram dalam Kej. 12:1, LAI menggunakan redaksi 'berfirmanlah 'Tuhan' kepada Abram. Alkitab, (Jakarta: Percetakan Lembaga Alkitab Indonesia, 1996), cet. ke-6, 10. Lihat pula: Karen Armstrong, In the Beginning: A New Interpretation of Genesis, (London: Vintage, 2011), 18, dan 60 .

${ }^{11}$ John H. Hayes dan Carl R. Holladay, Pedoman Penafsiran Alkitab (Jakarta: Bpk Gunung Mulia, 1993), 52.
} 
memperoleh pemahaman tentang teks, meskipun siapa sesungguhnya penulis teks tidak diketahui. ${ }^{12}$

Kebanyakan tafsir Alkitab pada masa lalu memanfaatkan berbagai rujukan atas teks yang pararel, semisal dokumen sejarah. Dimensi sejarah dari dokumen kedua ini semestinya diteliti oleh penafsir. Dalam bahasan kali ini saya juga menggunakan metode berupa penggunaan dokumen pararel yang digunakan oleh peneliti-yakni yang ditulis oleh Flavius Josephus (37-38 S.M. sampai \pm 100 M). Flavius adalah sejarawan yang berjasa menulis sejarah umat Yahudi dalam konteks pembaca masyarakat Kerajaan Romawi Kuno. Karya Antiquities Judaicae (Judean Antiquities) tahun 93 M. ditulis untuk orang dari luar tradisi Yahudi yang ingin mengetahui seluk beluk Yudaisme. ${ }^{13}$

G. E. Lessing menandaskan (1729-1718) bahwa wahyu Ilahi tetap melekat dan sementara berkarya lewat teks Alkitab. Jadi, walau wahyu itu datang dan menyapa kita lewat sejarah dan tangan manusia, wahyu atau teks Alkitab itu tidak bisa dibaca dan ditemukan nilai kebenarannya semata-mata lewat fakta-fakta kesejarahan, tetapi lewat "pemaknaan" hakikat yang terkandung dari sejarah atau nilai sejarahnya. Sementara ahli filsafat sejarah, von Herder (1774-1803), mengatakan: walaupun Alkitab sepenuhnya adalah karya manusia tetapi ia tidak bisa didekati dengan cara penelitian kesejarahan. Alkitab semestinya dipandang sebagai suatu karya sastra yang dapat memungkinkan pembaca mengalami suatu "pengalaman yang hidup" dari sejarah. Lessing dan von Herder mewakili mereka yang mendekati teks Biblikal dari aspek literary criticism (penelitian kesusastraan). ${ }^{14}$

Penelitian kritis historis dilakukan oleh G.W.F. Hegel pada 1784. Dalam kuliah filsafat sejarah yang diberikan antara tahun 1822 hingga 1832, Hegel menyampaikan pandangannya bahwa sejarah tidak diketabui pasti dengan adanya fakta-fakta saja, tetapi dipabami dengan alasan-alasan mengapa fakta-fakta itu terjadi. Bertolak dari asumsi ini, Hegel tiba pada

\footnotetext{
${ }^{12}$ Ibid., 53.

13 Wendy Doniger (ed.), Merriam-Webster's Encyclopedia of World Religions, Springfield [Massachussets]: Merriam-Webster, inc., 1999), 580-1.

${ }^{14}$ S.O. Aitonam (LAI), "Pengantar: Karagaman Metoda Tafsir", dalam Forum Biblika: Jurnal Ilmiah Populer (Jakarta: Lembaga Alkitab Indonesia, No: 8, 1998), 4-5.
} 
konsep “dialektika sejarah" bahwa dalam proses sejarah universal (historyas-a-whole), kesadaran kosmis (spirit) akan menyatukan aspek-aspek sejarah individual yang kontradiktif sehingga membentuk sintesa "pengalaman". Dua sumbangan besar dari Hegel bagi dunia tafsir Alkitab modern adalah: 1) hakikat spirit sejarah yang paling hakiki tidak dapat dicapai melalui restorasi masa lampau, tetapi lewat mediasi dengan kehidupan kontemporer; 2) bagian-bagian sejarah individual harus dilihat dan dipahami sebagai bagian dari keseluruhan. ${ }^{15}$

Reaksi terhadap pandangan filsafat sejarah Hegel yang universal ini dinyatakan oleh Von Ranke (1795-1886). Dia memandang bahwa Hegel mencampuradukkan filsafat dengan ilmu pengetahuan. Oleh karena itu, ahli sejarah modern ini mengajak kepada ilmu pengetahuan yang murni tentang sejarah. Menurut dia, sejarah hanya sebatas apa yang benar-benar terjadi (Wie es eigentlich geweesen). Sejarah itu memiliki kekhasan tersendiri dipelajari seobjektif mungkin tanpa disandangkan dengan konsep-konsep filsafat. Bagaimanapun juga, von Ranke tidak dapat mengelakkan sejarah itu sendiri dari persoalan-persoalan filosofis sang sejarawan-yang di dalam hermeneutika disebut sebagai pra-paham (preunderstanding). ${ }^{16}$

Perbedaan pandangan antara Hegel dan Von Ranke terus berlanjut, bahkan mulai memasuki wilayah agama dan semakin terasa gemanya dalam pandangan hermeneutika W. Dilthey (1833-1911), metode historis Ernst Troelsch (1865-1929), dan pandangan teologi R. Bultmann (1884-1976) yang mengharuskan baik sejarawan maupun penafsir memindahkan dirinya dari masa kini ke masa lampau untuk "memahami kembali" (re-experience atau Nacherleben) pengalaman asli masa lampau (experience atau Erlebnis)-pandangan-pandangan yang di kemudian hari dikritik oleh Karl Barth (1889-1968) lewat ajakan kembali ke konsep "sejarah yang sakral" (sacred history) yang sangat kuat di kalangan teolog. ${ }^{17}$

\footnotetext{
15 Ibid., 5-6.

${ }^{16}$ Ibid., 6.

${ }^{17}$ Ibid., 5
} 
Membahas aspek kesejarahan teks-teks biblikal melalui kajian tafsir Alkitab saat ini menjadi penting untuk memecahkan problem rumit seputar sejarah Israel. Oleh karena itu, selain dengan pendekatan teologis sejarah yang sakral, penulis juga akan mendekatinya dengan pendekatan arkeologi biblikal. Arkeologi adalah sumber yang menjadi landasan penelitian sejarah, bukan sebatas disiplin alat bantu yang sederhana. Data arkeologis merupakan dokumen sejarah pada dirinya sendiri, bukan sekadar gambaran yang mengilustrasikan teks kesejarahan tertulis. Sebagaimana sejarawan, para arkeolog berupaya membangun kembali proses-proses yang membangun dunia manusia-termasuk diri kita sendiri sebagai makhluk yang hidup pada suatu periode dan dalam lingkungan sosial tertentu. ${ }^{18}$

Kata arkeologi berasal dari bahasa Yunani arkhêe (permulaan) dan logos (perkataan, ilmu). Dalam bahasa Indonesia sering disebut dengan "ilmu purbakala", atau "kepurbakalaan". Arkeologi dapat dipahami sebagai penelitian tentang kehidupan manusia pada zaman kuno. Seorang arkeolog dengan demikian adalah orang yang senantiasa berusaha mendalami perihal zaman kuno dengan meneliti sisa peninggalan, yakni tipe kultur yang melatarbelakanginya dan disepakati dalam lingkup masyarakatnya masing-masing. ${ }^{19}$

Jadi, arkeologi Alkitab adalah suatu ilmu pengetahuan (sains) yang baru muncul pada akhir abad ke-19. Akan tetapi, sejak tahun-tahun pertama kekristenan telah ada upaya dari para pengembara meneliti tempat-tempat yang menjadi lokasi peristiwa kesejarahan dalam Alkitab. Adapun pada abad ke-21, pembuktian kebenaran peristiwa-peristiwa tertentu dalam Alkitab belum memberikan bukti definitif tentang hal itu. Arkeologi Alkitab dengan demikian adalah disiplin yang menyediakan informasi berkenaan dengan kebiasaan ciri kehidupan manusia pada zaman Alkitab. Disiplin ini membantu kita memahami Alkitab dengan lebih baik apabila kita mengetahui gaya hidup dan kebudayaan manusia yang pertama sekali menerima firman Allah. ${ }^{20}$

\footnotetext{
${ }^{18}$ V. Gordon Childe, A Short Introduction to Archaeology, (New York: Collier, 1962), 9.

${ }^{19}$ Ibid., 18.

20 David L. Baker dan John J. Bimoson, Mengenal Arkeologi Alkitab (Jakarta: Bpk Gunung Mulia, 2004), 28.
} 
Buku Philip J. King dan Lawrence E. Stager berjudul Kebidupan Orang Israel Alkitbiah menegaskan bahwa arkeologi Alkitabiah ditujukan untuk menerangi tokoh-tokoh besar dan peristiwa-peristiwa yang membentuk orang-orang Israel, dengan upaya menemukan sisa-sisa peninggalan masa lalu bahkan dari peristiwa kehancuran dan peristiwa katastropik. ${ }^{21}$ Arkeologi Alkitabiah juga dapat disebut dengan arkeologi kawasan, tempat kejadian peristiwa-peristiwa di dalam Alkitab. W.F. Albright menyebutnya dengan The Archaelogy of Palestine (1951) yakni tentang arkeologi pada periode-periode kritis sejarah Israel. Seiring dengan semakin banyaknya temuan di bidang ini, kita akan menemukan semakin banyak informasi.

\section{Asal Usul Bangsa Israel}

Pada abad ke-19 para ahli mendapat landasan yang mendasari deskripsi tentang bangsa Ibrani melalui sekumpulan tulisan-tulisan di atas tanah liat dalam bahasa Akkad yang ditemukan di Mesir pada tahun 1887, di dekat kampung Amarna. Lembaran-lembaran tertulis itu adalah surat-surat yang ditulis beberapa pemimpin kota di Kana'an dan Syria kepada Firaun Amenofis III (memerintah 1390-52 S.M.) dan Amenofis IV (juga bernama Akhenaten 1352-36 S.M.). Surat-surat tersebut saat ini dikenal dengan nama "surat-surat Amarna".2 Beberapa surat ini menyinggung orang-orang yang disebut dengan Habiru (Hapiru): mereka adalah orang-orang Israel yang keluar memasuki tanah Kana'an ${ }^{23}$ di bawah pimpinan Joshua. Orang Israel sering dipanggil dengan "orang Ibrani" atau "orang Heber" hampir mirip-mirip dengan sebutan Habiru. Nama Habiru juga disebut-sebut dalam beberapa tulisan Mesir dengan

${ }^{21}$ Philip J. King dan Lawrence E. Stager, Kebidupan Orang Israel Alkitbiah (Jakarta: BPK Gunung Mulia, 2010), 7.

22 Ibid., 9. Menurut Joseph P. Free dan Howard F. Vos, sumber ini dianggap sebagai versi orang Kana'an. David L. Baker dan John J. Bimoson, Mari Mengenal Arkeologi Alkitab, 95.

${ }^{23}$ Josephus, Jewish Antiquities, Book I, chapter 7: 155, 21 
nama Apiru yang berarti "para budak". Tampaknya nama ini merujuk kepada waktu kepergian orang Israel dari Mesir, yakni abad ke-15 S.M. ${ }^{24}$

Berbagai hasil penelitian menandaskan bahwa orang-orang Habiru adalah penyerbu bukan dari luar Kana'an. Mereka adalah bagian dari suku Kana'an yang memberontak terhadap sistem politik waktu itu. Jadi, Habiru bukan nama suatu bangsa melainkan istilah sosial-politik yang berupaya melepaskan diri dari sistem monarki Mesir atau kekuasaan seorang penguasa. Meski demikian, Mari Mengenal Arkeologi Alkitab (2004) ${ }^{25}$ menegakkan bahwa surat-surat (lempengan-lempengan Amarna) itu tidak bisa digunakan sebagai bukti keluarnya bangsa Israel dari Mesir. Pada masa-masa yang belum diketahui, demikian juga menurut Kebidupan di Timur Tengah Kuno (3100-332 S.M.), Firaun Merneptah (sekitar 1209 S.M.) berhasil mematahkan bangsa Israel. Justru penelitian belakangan menunjukkan bahwa pertumbuhan penduduk di kawasan tidak semuanya datang dari padang pasir, melainkan orang nomad—sebagaimana bangsabangsa kuno lain di kawasan-yang berbaur dengan para pengungsi dari negara-negara kota zaman kuno. ${ }^{26}$ Mungkin inilah yang mendorong Roger Garaudy melakukan kritik keras pada akar klaim Zionisme dan "hak kembali Israel" atas tanah kawasan kuno itu.

Sebagian dari kelompok pengembara ini (pendatang baru etnis Israel) ada yang terus menetap di daerah Kana'an. Sementara kelompokkelompok lainnya yang meneruskan perjalanan mereka, sehingga akhirnya (sebagian) mereka sampai di Mesir. Kelompok bangsa-bangsa pengembara yang disebutkan tadi (di antara mereka itu terdapat kelompok yang kemudian dinamakan bangsa Ibrani) meminjam serta

\footnotetext{
24 Pandangan ini dibantah sejak istilah 'Hapiru' lebih umum dampaknya dan bisa diartikan dengan konteks 'golongan yang tidak memiliki banyak hak pada masa-masa biblikal itu. Jadi, bangsa Israel lebih diartikan sebagai bangsa yang memang keluar dari Mesir pada masa Fir'aun Meneptah (1223-1211 S.M.). lihat: David F. Hinson, Sejarah Israel pada Zaman Alkitab, (Jakarta: BPK Gunung Mulia, 1993), 61-2. Lihat pula: David L. Baker dan John J. Bimoson, Mengenal Arkeologi Alkitab), 96.

25 Ibid., 34.

${ }^{26}$ Daniel C. Snell, Kehidupan di Timur Tengah Kuno 3100-332 S.M. (Jakarta: Bpk Gunung Mulia, 2009), 147.
} 
memungut dari orang-orang Kana'an: bahasa, tulisan dan (sistem) agama mereka hingga sekitar kurang lebih 1400 S.M. ${ }^{27}$

Sumber-sumber biblikal awal yang ditulis pada abad ke-18 S.M. menegaskan bahwa nenek moyang bangsa Israel merujuk kepada nama Abram, bapak monoteisme, Musa, Joshua dan Daud. Dalam PL, disebutkan bahwa Abram adalah putra Terah keturunan Shem. Terah membawa putranya dan menantunya Sarai, dari kota asal mereka UrChaldea (Mesopotamia) ke tanah Kana'an (Kej. 11:32). Sedangkan Armstrong dalam The Great Transformation (2006) menandaskan ekskavasi arkeologis sejak tahun 1967. Tidak ada petunjuk jejak destruksi massal sebagaimana yang dikisahkan dalam kitab Joshua (6: 24), tidak ada bukti adanya invasi bangsa luar, tidak pula artefak bangsa Mesir, begitu pula perubahan komposisi penduduknya. Silang pendapat di kalangan para sarjana begitu sengit. Hanya terdapat konsensus di kalangan mereka bahwa kejadian Eksodus dari Mesir tidak historis, karena ditulis jauh sesudah kejadiannya. ${ }^{28}$ Armstrong secara garis besar menyimpulkan bahwa meski mereka bukan komunitas di luar bangsa Kana'an, tetapi lebih memandang diri mereka sebagai bangsa asing di sana menunjukkan persaingan antar kelompok etnis di kawasan, sehingga dapat ditegaskan mereka bukan hanya memiliki satu nenek moyang. Kesadaran mereka akan perjanjian yang sama-sama dipegang adalah bentuk penolakan terhadap sistem sosial urban bangsa Kana'an. Bentuk kehidupan di pinggiran kultur bangsa Kana'an merupakan karakter utama bangsa Israel yang menegaskan mereka adalah bangsa dari luar dapat dirasakan dari polemik dalam Biblikal yang anti-Kana'anites. ${ }^{29}$

\section{Sejarah Bangsa Ibrani}

Allah memanggil Abram, "Pergilah dari negerimu dan ayahmu ke tanah yang Aku tunjukkan kepadamu. Aku akan membesarkan

\footnotetext{
${ }^{27}$ R. Garaudy, Zionis Sebuah Gerakan Kaeagamaan dan Politik (Jakarta: Gema Insani Press, 1993), 71.

${ }^{28}$ Karen Armstrong, the Great Transformation: the Beginning of Our Religious Traditions (New York, NY: Anchor Book, 2006), 46.

${ }^{29}$ Ibid., 46-7.
} 
namamu." (Kej. 12:1)..$^{30}$ Karena Abraham membawa pandangan tentang keesaan Tuhan, dia diusir oleh bangsa Mesopotamia dan Chaldea ke tanah Kana'an. Di sana dia membangun altar dan melakukan pengorbanan kepada Allah. Josephus mengutip dari Nicolaus of Damascus tentang kisah Abram yang menjadi orang asing dari tanah Chaldea, di kawasan yang saat itu diberi nama tanah bangsa Kana'an (tanah Judea). ${ }^{31}$ Sempat tinggal di Mesir, ia lantas berdiam di Hebron. Di tengah perjalanannya, pada suatu tempat di tanah Kana'an (di dekat Shechem) Tuhan menampakkan diri-Nya dan menjanjikan, "Kepada benih keturunanmu, Aku akan berikan tanah ini." Abram lantas mendirikan altar untuk Tuhan sebagai peringatan di sana, (Kej. 12:7).

Tatkala menerima perjanjian dari Tuhannya, Abram diberi gelar sebagai Abraham-bapak bangsa-bangsa. Allah berfirman kepadanya: "Camkanlah, bahwa anak-anak keturunanmu akan menjadi asing di tanah bukan milik mereka, dan ... mereka (keturunanmu) ke tanah (Perjanjian) ini dalam empat generasi. (Kej. 15: 13-16). ${ }^{32}$ Pada waktu itu dia belum memiliki putra sebagai pewarisnya. Namun, Allah berfirman kepada Abram, "Aku akan membuatmu berketurunan." (Kej. 17:2). Oleh istrinya, Sarai, Abram didukungnya agar dapat memperoleh seorang putra melalui salah putri dari Mesir-Perjanjian Lama menyebut 'budak perempuan dari Mesir'bernama Hagar (Kej. 16:1) yang lantas diperistri oleh Abram. Baru saat dia berumur 87 tahun, dia memiliki putra Ismail: Allah telah mendengar. ${ }^{33}$ Kemudian Abram memiliki seorang putra melalui Sarai pada usia 99 tahun, dan diberi nama Ishak (yang berarti "tertawa", karena istrinya

\footnotetext{
${ }^{30}$ Dari dia gagasan tentang keesaan Allah—sang Pencipta alam ini berawal. Kuasakuasa lain yang memiliki kekuatan tidak memiliki kekuatan sendiri, tetapi oleh karena Dia yang memerintah mereka, konsekuensinya manusia hendaknya memberikan persembahan dan penghormatan kepada-Nya. F. Josephus, Jewish Antiquities, chapter 6:136, 19 .

31 Josephus, Jewish Antiquities, Book I, chapter 7: 159, 22.

32 Referensi kepada Alkitab mengacu pada: The Holy Bible: New Revised Standard Version, yang diterbitkan oleh the Division of Christian Educaion of the National Council of Churches of Christ in USA, (Michigans: Zondervan Publishing House, 1989), 10.

${ }^{33}$ Yang kelak pergi ke padang belantara.
} 
tertawa seakan tidak percaya dengan kabar gembira putranya yang baru). ${ }^{34}$

Sejak itu Abraham menerima dan memegang teguh janji-janji (covenants) dari Tuhannya dengan berkhitan. Nama Sarai digantikan dengan Sarah. (Kej. 18:13). Abraham selanjutnya mendapatkan ujian kesetiaannya atas Allah dengan mengorbankan putranya -tetapi akhirnya digantikan dengan anak domba (ram) (Kej. 24: 9-13). Sarah meninggal dalam usia 127 tahun (Kej. 23:1), sedangkan Abrahamsetelah usia 175 tahun dalam hidupnya-dimakamkan oleh kedua putranya (Ismail dan Ishak) di Machpelah serta dihadiri oleh orang-orang Het (Hittites) (Kej, 25: 7-9). Para ahli memperkirakan bahwa kedatangan para leluhur Israel (patriakh) ke kawasan pada Periode Penggunaan logam Tembaga Pertengahan pertama, tetapi bisa jadi mereka datang lebih belakangan. ${ }^{35}$

Ismail dan keturunannya kelak mendiami kawasan sejak dari Euphrate sampai ke Laut Merah-di tanah yang lantas dinamakan dengan Nabatea. Mereka adalah bangsa Arab yang memiliki beberapa suku dan dua aspek kehormatan: nilai-nilai yang mereka pegang dan kehormatan dari segi mereka adalah keturunan Abraham. ${ }^{36}$ Ishak berputrakan Essau dan Yaqub. Pada suatu saat, Yaqub bermimpi melihat tangga ke surga dan Allah menjanjikan kepadanya bahwa keturunannya akan menjadi bangsa yang besar. ${ }^{37}$ Sebagai peringatan dia menandai batu tempat dia bermimpi dan mempersembahkan korban di atasnya. Tempat itu dijadikan tempat pemujaan bernama Bethel—yang diterjemahkan kemudian dengan "rumah Allah". Yaqub tinggal di tanah Kana'an yang disebut dengan Shechem. ${ }^{38}$

Yusuf adalah putra Yaqub dari istri yang dicintainya, Rachel. Yusuf diasingkan, dan dalam PL, dijual (Kej. 37:25-8) oleh saudarasaudaranya sampai dia tinggal di Mesir. Kemudian ia diambil dan diasuh oleh salah seorang pejabat yang mengatur rumah tangga dan masakan

\footnotetext{
${ }^{34}$ Josephus, Jewish AntiquitiesBook I, chapter 10: 186-5, 25. Lihat Kej. 17: 12-5.

${ }_{35}$ Snell, Kehidupan di Timur Tengah Kuno, 75.

${ }^{36}$ Josephus, Jewish Antiquities, Book I, chapter 12: 220-1, 29.

${ }^{37}$ Ibid., chapter 19 :279-84, 37. Lihat: Kej. 28: 10-1.

${ }^{38}$ Ibid., chapter 21: 337, 44.
} 
Firaun, bernama Potiphar. ${ }^{39}$ Masalah kecintaan istri pejabat itu kepada Yusuf, membuat dia dipenjarakan, atas sikap keteguhannya menahan $\operatorname{dir}^{40}$ dari godaan itu. Visi rekan-rekannya di penjara membuat kasusnya diingat kembali dan dihadapkan kepada raja yang mempercayakannya takwil visinya. ${ }^{41}$ Yusuf pada akhirnya diamanati sebagai bendahara raja dan memiliki putra Manasseh. Dengan kedudukannya yang mulia itu, Yusuf memanggil dan mengundang ayahnya dan saudara-saudaranya tinggal di Mesir. ${ }^{42}$ Sejak itu, keturunan Yaqub tinggal di salah satu tempat bernama Gosyen timur laut delta sungai Nil, di Mesir (Kej. 47: 6). Kisah Yusuf diperkirakan dimasukkan pada abad ke-18 S.M. ${ }^{43}$

Dalam episode bangsa Ibrani tinggal di Mesir, di dalam tulisantulisan JA, Musa bin Amram menjadi figur sentral pembicaraan waktu itu. Menghindari dampak kesalahannya menolong sesama orang Ibrani yang disiksa orang Mesir-sampai Musa membunuh orang Mesir itu (Kel. 2: 11-4) Musa lekas-lekas pergi ke perkampungan Jethro-yang disebut-sebut sebagai tanah bangsa Midian (Kel. 3: 25 \& 26). Di sana, dia mengunjungi tempat suci di atas gunung dan beraudiensi dengan Allah, sekali lagi disebutkan tentang janji-Nya untuk membawa kembali bangsa Ibrani ke tanah leluhur mereka sebagaimana yang telah dijanjikan ${ }^{44}$ kepada Abraham.

\section{Keluar dari Negeri Mesir}

Demi melepaskan Israel dari penindasan Firaun Mesir, Musa melakukan berbagai mukjizat yang mendorong raja Mesir memerintahkannya keluar dari negeri Mesir (Kel. 13: 33). Upacara tanggal 10 Nisan memperingati pengorbanan dan persiapan bangsa Ibrani membawa apa saja yang mereka miliki. Upacara ini disebut dengan

\footnotetext{
39 Josephus, Jewish Antiquities. Book II, chapter 4: 39, 51. Kej. 39: 1, salah seorang 'pejabat'.

40 Ibid., chapter. 4: $42 \& 48,52$.

${ }^{41}$ Ibid., chapter 5: 80-8, 57.

42 Ibid., chapter. 8: 194, 70.

${ }^{43}$ Baker dan Bimoson, Mengenal Arkeologi Alkitab, 85-6.

${ }^{44}$ Josephus, Jewish Antiquities, Book II, chapter 12: 264-9, 79.
} 
upacara Pesah (Passover). ${ }^{45}$ Di tengah-tengah perjalanan ke luar dari Mesir, bangsa Ibrani mengalami kekurangan pangan dalam perjalanan mereka, sehingga selama tiga puluh hari hanya mengonsumsi raghef (roti kering) yang dipanaskan.

Memori peringatan mengenang peristiwa ini dirayakan pada festival roti tidak beragi (the feast of unleavened bread). Bangsa Ibrani menyeberangi lautan yang terbelah (Kel. 14: 21-2), menghindari kejaran tentara Mesir, ${ }^{46}$ dengan bimbingan Musa, yang membawa Israel ke Gurun Sinai. Di Padang Sinai, bangsa Ibrani menerima nikmat Allah berupa manna ${ }^{47}$ (dari bahasa Ibrani man bu yang berarti siapakah ini. Lihat Kel. 16:5). Musa, dibantu oleh penggantinya kelak-Joshua, menaklukkan bangsa Amalek dengan kekerasan (by force) dan memerangi negara-negara tetangganya. Keberhasilan mereka dalam proses penaklukkan dirayakan dengan rasa syukur oleh Musa dalam upacara pengorbanan persembahan kepada Tuhan sang Penakluk (The Lord, the Conqueror.$^{48}$

Musa pergi ke gunung Sinai dan beraudiensi dengan Allah yang memberi dasa titah kepada bangsa Ibrani bahwa: 1) Tidak ada tuhan selain Allah yang satu; 2) Hanya Dia yang patut disembah; 3) Tidak diperkenankan membuat citra (image) dari makhluk hidup sebagai perantara dalam penyembahan dan menyebut Nama Tuhanmu dengan sia-sia; 4) Jangan bersumpah palsu; 5) Menjalani Hari Sabbath dengan menghentikan semua pekerjaan; 6) Menghormati dan mematuhi orang tua; 7) Jangan berzina; 8) Jangan berbuat dosa dengan mencuri; 9) Jangan memberi kesaksian palsu, dan; 10) Jangan menginginkan kepunyaan orang lain. ${ }^{49}$

Musa lantas membangun tenda Tabernakel yang dinamakan 'Bait Suci' (Holy Place), dan bagian yang paling suci dinamakan dengan Yang Maha Kudus (Holy of Holiest). ${ }^{50}$ Musa secara khusus menentukan suku

\footnotetext{
45Ibid., chapter.14: 313-14, 85.

${ }^{46}$ Ibid., chapter. 18: 338, 80.

${ }^{47}$ Josephus, Jewish Antiquities, Book III, chapter. 1: 32, 95.

48 Ibid., chapter. 3: 60-1, 98.

${ }^{49}$ Ibid., chapter. 5: 89-92, 102. Lihat: Kel. 20: 2-17.

${ }^{50}$ Josephus, Jewish Antiquities, Book III, chapter 5: 125, 106.
} 
Levi menjadi imam bagi bait Allah, ${ }^{51}$ dan mengadakan upacara kurban paskah dari belantara (passover in the wilderness), begitu dia telah keluar dari tanah Mesir. ${ }^{52}$ Setelah saudarinya wafat, pada tahun yang sama, Musa merasakan menjelang akhir hayatnya saat usianya yang ke-130 tahun. Harun tutup usia pada hari pertama bulan menurut perhitungan lunar di bulan $A b b a^{53}$

\section{Penaklukkan atas Negeri Kana'an}

Pasukan Israel yang dipimpin oleh Musa telah mencapai kota dekat sungai Jordan. ${ }^{54}$ Musa meninggal sebagai pemimpin Bani Israel dalam usia seratus dua puluh tahun di bulan Âdar. Kepemimpinan militer jatuh ke tangan Joshua, ${ }^{55}$ yang melanjutkan peperangan dengan bangsa Kana'an (Canaanites) menyeberangi Jordan. ${ }^{56}$ Berikut deskripsi $J A$ tentang penaklukkan-penaklukkan bangsa Israel:

"Kini, tatkala Bani Israel melakukan persiapan (pertempuranpen.), bangsa Kana'an tidak melakukan penyerangan. Joshua memutuskan untuk mengepung mereka. Maka dari itu, pada hari pertama festival passover, para imam pendeta mengusung Tabut (ark) ke mana-mana, dengan pasukan pengawal. Para Imam Pendeta meniup sangkakala memicu keberanian pasukan, dan berhambur mengepung kota... sampai enam hari. Pada hari ketujuh, Joshua mengumpulkan pasukan dan orang-orang, serta menyampaikan kabar gembira bahwa kota akan segera direbut, sejak Tuhan pada hari itu juga menyerahkan (kota itu) ke tangan mereka, dengan merobohkan tembok pertahanan...

Dia lantas memberi aba-aba untuk membunuh siapa saja dari bangsa Kana'an di kota yang mereka bisa hadapi dan tanpa menyisakan

\footnotetext{
${ }^{51}$ Ibid., chapter 11: 258, 121. Lihat: Bil. 18: 1. "Harun, kamu dan putra-putramu, dan baris keturunanmu hendaknya mengambil tanggung jawab...berkaitan dengan jabatanmu sebagai imam.

52 Josephus, Jewish Antiquities, Book III, chapter 12: 294, 125.

53 Josephus, Jewish Antiquities, Book IV, chapter 3: 83-4, 141.

${ }^{54}$ Ibid., chapter 5: 95 dan 6: 100, 143-4.

55 Ibid., chapter 8: 327 dan Book V. chapter 1:1, 172-3.

${ }^{56}$ Josephus, Jewish Antiquities, Book V, chapter 1:16, 174.
} 
musuh mereka-hingga mengejar musuh yang kabur. Dia memerintahkan mereka, semuanya, untuk mengumpulkan emas dan perak, yang bisa dijadikan sebagai buah hasil yang diperuntukkan bagi Allah." ${ }^{57}$

Begitulah, mereka (Bani Israel) masuk kota Jericho, membantai setiap laki-laki yang berada di dalam kota itu. Warga Jericho tak mampu mempertahankan diri; hingga mereka semua tewas terbunuh dengan tenggorokan disembelih—sebagian di jalan-jalan, lainnya terjebak di rumah. Bahkan, mereka semua binasa, sampai para wanitanya dan anakanak sekalipun. Mayat-mayat bergelimpangan: tidak seorang pun yang lolos. Mereka (Bani Israel) membumihanguskan kota berikut daerah pinggiran sekitarnya. ${ }^{58}$

Bangsa Israel lantas terlibat konflik dengan bangsa Philistine, salah satu bangsa penakluk yang membuat gentar bangsa Israel dalam pertempuran. Diputuskan bahwa Tabut-yang menjadi sumber kekuatan bangsa Israel-akan dibawa oleh Imam Tinggi (bigh priest) dalam barisan untuk meneguhkan kekuatan bangsa Israel. Akan tetapi, di luar dugaan, pertempuran dimenangkan oleh orang-orang Philistine, ${ }^{59}$ orang Israel kehilangan ribuan pasukan. Di antaranya putra-putra imam tinggi; bahkan Tabut dirampas oleh lawan dan diboyong ke kota Philistine. Berita duka kekalahan ini sampai ke kota Shiloh dan ditangisi di dalam kota. Di Ashdud, kota Philistine, Tabut yang dirampas membawa bencana dan kesialan bagi penduduknya (1 Sam. 5: 1-6), sehingga dipindahkan ke kota Ashkelon. Di sana, penduduknya mengalami kemalangan yang sama, sehingga gubernur kota-kota Philistine (Gath, Ekron, Ashkelon dan Gaza) sepakat mengembalikannya ke bangsa Israel. ${ }^{60}$ Tabut kini berada di kota Kiryat-Jearim (1 Sam. 7:1-2).

\footnotetext{
${ }^{57}$ Ibid., chapter 1: 22-5, 175. Lihat: Yos. 6: 24.

58 Ibid., chapter 1: 28-9, 176. Dalam Yos. 6: 21, bangsa Israel bahkan membunuh orang tua dan muda, keledai, biri-biri dan lembu.

${ }^{59}$ Ibid., chapter 11: 352-7, 214-5. Lihat: 1 Sam. 4: 10-1.

${ }^{60}$ Ibid., chapter 1:1-3 \& 8. h. 219.
} 


\section{Perdebatan tentang Penaklukan Negeri Kana'an}

Tulisan Mengenal Arkeologi Alkitab (2004) menegaskan, meski diakui adanya kekurangan bukti bahwa pendudukan tanah Kana'an (misalnya, kota Jericho) oleh bangsa Israel memang terjadi pada masa sekitar 1400 S.M. ${ }^{61}$ Pendapat ini disetujui pula oleh Arkeologi dan Sejarah Alkitab (2001), dengan mengutip penelitian Katheleen Kenyon yang dilakukan untuk British School of Archeologi di Yerusalem pada 1952-8. Pada lapisan neolitik di Jericho menentukan tahun yang lebih muda antara 1350-1325 S.M., sehingga invasi Israel atas tanah Kana'an menimbulkan perdebatan panjang sampai kini. ${ }^{62}$ Orang Israel yang kini berdiam di tengah-tengah orang Kana'an mungkin sekali meniru tembikar dan arsitektur di sana. Dari sudut pandang penemuan dan penelitian arkeologis, mereka dapat dibedakan dari orang Kana'an asli. Bisa jadi pula, orang Israel lain lebih suka dengan gaya hidup nomad sampai mereka menetap pada permulaan zaman besi. Menurut Karen Armstrong penaklukkan Joshua di negeri Kana'an tidak total. Kita diberitahu bahwa dia tidak dapat mengalahkan negara-kota Kana'an tidak pula kemajuan apa pun dalam melawan bangsa Philistine. Pandangan saksama terhadap bagian pertama dua belas pasal Kitab Joshua menunjukkan bahwa kebanyakan aksi mencakup sebagian kecil saja wilayah area suku Bunyamin. Begitulah, Bibel meninggalkan kita dengan kesan yang jelas sekali bahwa penaklukkan Jopshua merupakan peristiwa yang tidak terjadi. Meski begitu masih terdapat banyak sarjana-terutama di Israel dan Amerika Serikat-yang mempercayai bahwa orang-orang Israel memang menaklukkan negeri itu dengan cara yang telah disebutkan. Tetapi para sarjana lain menyimpulkan bahwa sebagai ganti akan adanya erupsi kekerasan pada bangsa Kana'an dari luar, bangsa Israel muncul secara damai dan gradual dari dalam (from within) kalangan masyarakat Kana'an sendiri. ${ }^{63}$

${ }^{61}$ Baker dan Bimoson, Mengenal Arkeologi Alkitab, 124.

${ }^{62}$ Joseph P. Free dan Howard F. Vos, Arkeologi dan Sejarah Alkitab (Malang: Yayasan Penerbit Gandum Mas, 2001), 168-9.

${ }^{63}$ Karen Armstrong, Jerusalem: One City, Three Faith (New York: Ballantibe Books, 2005), 23. 


\section{Kelahiran Monarki Israel}

Pelanjut kepemimpinan Israel lantas berada di tangan Samuel, sang nabi. Dia menempatkan diri sebagai atasan mereka dengan menegakkan keadilan dan membina ketenteraman di kalangan mereka. ${ }^{64}$ Sumber PL (1 Sam. 8: 1-13) menyebutkan desakan bangsa Israel kepada nabi Samuel untuk mendirikan monarki. Allah menampakkan diri atas nabi Samuel bahwa Dia akan menunjuk raja dari kalangan mereka sendiri. ${ }^{65}$ Nabi Samuel menanggapi desakan mereka yang menginginkan seorang raja dari mereka. Dia berkata bahwa mereka hendaknya pergi ke penjuru kampung, dan dia akan menunjuk seseorang-atas petunjuk Allah-yang pantas menjadi raja mereka. ${ }^{66}$ Samuel melihat, dengan petunjuk Tuhan, tanda-tanda bahwa Saul layak menjadi pemimpin mereka. ${ }^{67}$ Saul segera disumpah sebagai raja untuk menaati Allah dan Hukum Musa.

Prestasi Saul, sebagai raja, adalah keberhasilannya menaklukkan bangsa Amalek yang berasal dari Pelusium (Mesir) sampai Laut Merah (1 Sam. 15: 8). ${ }^{68}$ Namun, peristiwa-peristiwa selanjutnya memperlihatkan perselisihan yang timbul antara Samuel dan Saul. Samuel mendengar tentang Daud, penggembala, yang dipanggil dan diurapinya; nabi itu membisikkannya untuk selalu menaati perintah Allah dan berbuat kebaikan (righteous). ${ }^{69}$ Perpindahan pilihan dari Saul ke Daud ini secara tradisional ditafsirkan oleh F. Josephus ${ }^{70}$ sebagai persetujuan yang pergi dari diri Saul. Bahkan, Kuasa Ilahiah telah berpindah dari dia, dan tinggal dalam diri Daud. Sekarang, pada diri Daud terdapat Roh Ilahi yang menandai kenabian.

Saul merasa cemas dan mencari remaja penggembala itu. Daud menghadap dan mengabdi pada Saul. ${ }^{71}$ Pada saat itu, orang-orang Israel

\footnotetext{
${ }^{64}$ Josephus, Jewish Antiquities, Book VI, chapter 3: 31, 221.

${ }^{65}$ Ibid., Book VI chapter 3:39-9, 222.

${ }^{66}$ Ibid., Book VI chapter 3: 44, 223.

${ }^{67}$ Ibid., Book VI chapter 4: 52-3, 224.

${ }^{68}$ Ibid., Book VI chapter 6: 141, 236.

${ }^{69}$ Ibid., Book VI chapter 8: 164-5, 239.

${ }^{70}$ Ibid., Book VI chapter 8: 166.

${ }^{71}$ Ibid., Book VI chapter 8: 168 dan chapter 9: 275, 240-1.
} 
berperang dengan bangsa Philistine, yang dikomandani oleh Goliath dari kota Gath. Dia menantang duel pasukan orang-orang Ibrani. Daud berhasil membunuh dan Philistine kalah. ${ }^{72}$ Sebagai penghargaan, Daud dijanjikan akan dinikahkan dengan Michal, putri Saul. Kecintaan Allah dan khalayak kepada Daud mengkhawatirkan Saul. Ketika bangsa Philistine mengirim ekspedisi militer baru ke bangsa Ibrani, Saul mengirim Daud untuk menghadapi mereka. ${ }^{73}$ Kesalahpahaman terjadi antara Saul dan Daud-yang lantas menghindari istana rajanya. Demikianlah, Daud lari meloloskan diri dari pembunuhan terencana atas dirinya, ke kota-kota tanah bangsa Philistine, dan berpindah-pindah dari suatu lokasi ke lokasi lain. ${ }^{74}$

Samuel memberi kutukan kepada Saul atas ketidaktaatannya, sehingga Saul merasa bersedih. Pasukan Philistine menyerbu bangsa Israel dan banyak membunuh tentara raja Israel. Dengan susah payah, raja dan putra-putranya bertempur mati-matian mempertahankan diri. Pada akhirnya, putra-putra raja Israel, Jonathan, Abinadab dan Malchisua tewas. Orang-orang Ibrani lari menyelamatkan diri, termasuk Saul. ${ }^{75}$ Dalam sebuah pertempuran ia mati bunuh diri. ${ }^{76}$ Jenazah raja Saul dan putranya yang dimutilasi direbut kembali oleh penduduk Jabesh-Gilead dari musuh di Beth-shan dan lantas dimakamkan dengan layak (1 Sam. 31: 11-3).

Daud berduka-cita atas kematian raja dan putranya (1 Sam. 1:17), terutama Jonathan, putra tertua raja yang selama ini menjadi teman setia dan mengampuni nyawanya. ${ }^{77}$ Daud pergi ke Hebron dan dijadikan sebagai raja Judah. Pertikaian panjang terjadi antara pewaris Saul dengan istana (bayt). Melihat Daud semakin kuat posisinya, Abner yang memiliki

\footnotetext{
${ }^{72}$ Ibid., Book VI, chapter 9: 189, 242. Lihat 1 Sam. 17: 48-51

${ }^{73}$ Ibid., Book VI, chapter 11: 213, 245.

${ }^{74}$ Ibid., Book VI, chapter 13: 281, 254. Lihat: 1 Sam. 20: 30-5.

75 Ibid., Book VI, chapter 14: 368-70, 266.

76 Ibid., Book VI, chapter 14: 371-2, 266-7. PL melaporkan secara berbeda, dalam keadaan luka parah, Saul memerintahkan pengawalnya - atau setidaknya Saul mengira itu pengawalnya sendiri-untuk menusukkan pedang ke arahnya agar tangan 'orangorang yang tidak beriman' mengusik dirinya. Akan tetapi, pengawal itu terlalu ketakutan. Saul beranjak ke arah pedangnya yang terhunus dan tewas 1 Sam 31: 4-5).

${ }^{77}$ Ibid., Book VII, chapter 1: 7-10, 269-70.
} 
wewenang lebih luas bernegosiasi demi rekonsiliasi dengan raja baru, Daud. Dengan meninggalkan putra Saul, Daud kini menjadi raja seluruh bangsa Ibrani-atas nubuat Nabi Samuel. ${ }^{78}$

Dengan kelihaiannya, demikian menurut Josephus, Daud dapat menguasai dan memindahkan ibukota sekaligus memboyong Tabut ke Yerusalem. Selanjutnya, dia merebut kota itu dan menamainya dengan Ir David (kota Daud) dan membangun arsitektur istana kerajaan. Nama kota Yerusalem sendiri diambil dari Haekal Solayma yang berarti kemanan (keselamatan).

Arkeologi dan Sejarah Alkitab menandaskan bagaimana Yoab, panglima Daud, dapat menembus pertahanan kota Yerusalem. Yoab menemukan sistem air, naik ke jalan terusan dan memasuki kota pada malam hari lalu menyerahkannya kepada Daud. ${ }^{79}$ Sesuai nubuat, kelak Daud dan putranya, Sulaiman, mempersembahkan bait suci bagi Allah: dan untuk kepentingan itu pula Daud pergi ke rumah Araunah, orang Jebus, untuk meminta izin dan membeli sebidang tanah agar difungsikan sebagai tempat persembahan kepada Allah dalam upacara pengorbanan. Di sana, dia mendirikan altar untuk segala bangsa dan Bait suci untuk Allah. ${ }^{80}$ Daud meminta sumpah Sulaiman untuk membangun rumah Allah setelah resmi menerima penyerahan suksesi kerajaan.

Perselisihan tentang pengganti Daud diputuskan melalui anjuran nabi Nathan bersama-sama Imam Tsadek. Sulaiman dinobatkan sebagai pengganti ayahnya. Daud wafat dalam usia 70 tahun sebagai raja Judah dan raja seluruh negeri. Ia dimakamkan di Yerusalem. ${ }^{81}$ Sulaiman mampu meneguhkan pijakan kekuasaan dalam kerajaan dengan menghukum musuh-musuhnya, menikahi salah satu putri Firaun (Mesir), membangun lebih kokoh tembok Yerusalem, ${ }^{82}$ dan menerima utusan Hiram, raja Tyre (Sūr).

\footnotetext{
${ }^{78}$ Ibid., Book VII, chapter 1: 25 dan 27-9. 272. (2 Sam. 3: 12-20).

${ }^{79}$ Free dan Vos, Arkeologi dan Sejarah Alkitab, 202.

${ }^{80}$ Josephus, Jewish Antiquities, Book VII, chapter 13: 329-32, 311-2.

${ }^{81}$ Ibid., Book VII, chapter 15: 389-92), 319.

82 Ibid., Book VIII, chapter 2: 21, 323.
} 
Sulaiman meminta bantuan Raja Hiram memberikan suplai tenaga manusia dari dataran tinggi Lebanon untuk menebang kayu, karena penduduk Sidon itu adalah tenaga terampil dalam penebangan kayu dengan sejumlah bayaran yang dijanjikan oleh Daud-yang mendapat sambutan dari raja Hiram. ${ }^{83}$ Sulaiman mulai membangun bait Allah pada tahun keempat masa pemerintahannya dengan fondasi batu putih yang kokoh, atap, relung ruang yang lebar dan dinding dengan cedar yang kokoh dengan hiasan ornamen: bagian bait Allah itu dibagi duabagian intinya merupakan kamar rahasia. Kamar rahasia ini diisi dengan tabut, yang berbentuk cherubim. Untuk membayar kontribusi raja Hiram, Sulaiman memberi dia panen jagung per tahun, anggur dan minyak maupun beberapa kota di kawasan Galilee. ${ }^{84}$

Di antara berbagai pencapaian pada masa pemerintahan Sulaiman adalah keberhasilannya merebut sisa-sisa kawasan yang masih dipertahankan oleh orang Canaanites, terutama kawasan pegunungan Lebanon sampai Hamath. ${ }^{85}$ Sulaiman juga membangun armada kapal laut di salah satu teluk di Mesir, yang terletak di Laut Merah, bernama Eziogeber (pada zaman Josephus bernama Berenice) yang tidak jauh dari kota Eloth. Kota ini, menurut $J A$, telah dimiliki oleh bangsa Yahudi, dan digunakan bagi pembuatan kapal.

Meski dinilai menjalani kehidupan dengan kearifan (wisdom) dan kebajikan, Sulaiman dinilai berlebihan menikahi istri-istri dari bangsa lain, di antaranya putri Firaun Shesonk I (945-924 S.M.). Konsekuensinya, istri-istrinya itu menyembah dewa-dewa yang mereka yakini masingmasing. ${ }^{86}$ Sulaiman wafat dalam usia yang cukup lanjut, memerintah selama 80 tahun, dalam usia 94 tahun. $^{.7}$

\footnotetext{
${ }^{83}$ Ibid., Book VIII, chapter 2: 51-57, 327-8. Lihat: 2 Taw. 2: 3-11.

${ }^{84}$ Ibid., Book VIII, chapter 5: 141-2, 339.

85 Ibid., Book VIII, chapter 6: 160, 341.

${ }^{86}$ Ibid., Book VIII, chapter 7: 193-6), 346, dan 1 Raj. 11: 1-2.

${ }^{87}$ Ibid., Book VIII, chapter 7: 209-11, 347-8.
} 


\section{Pecahnya Kerajaan Israel: Judah dan Samaria}

Sebagai pengganti Sulaiman, putranya bernama Rehoboam ditabalkan menjadi pelanjut suksesi sang ayah. Di sisi lain, Jeroboam juga mengangkat dirinya menjadi raja. ${ }^{88}$ Rehoboam menjadi raja atas Judah dan suku Benyamin di Yerusalem dan Jeroboam menjadi raja atas kesepuluh suku lainnya di kota Shechem. Kerajaan di utara banyak mengalami pergolakan. Ketika Jeroboam meninggal, ia digantikan oleh Nadab, yang memerintah pada tahun kedua pemerintahan Asa, raja Yerusalem pengganti keturunan dinasti Daud-Sulaiman. ${ }^{89}$ Asa, dari dinasti di selatan (Yerusalem), yang terlibat konflik dengan tetanggatetangganya mengupayakan hubungan diplomatik dengan raja Damaskus. ${ }^{90}$ Sedangkan penguasa utara dibinasakan oleh Baasha, yang juga keburu meninggal di kota Tirza sehingga menghentikan rencana dia menyulut peperangan dengan tetangganya, raja Asa. Putra Baasha, Eloh memerintah selama 2 tahun, dan tewas justru di tangan pemimpin tentaranya, Zimri. Sesuai ramalan nabi Jehu, Zimri telah membantai keluarga Baasha—sekaligus menandai binasanya keturunan Jeroboam. ${ }^{91}$ Zimri sendiri terkepung oleh musuh-musuhnya, menyingkir ke dalam kota membakar istananya, termasuk dirinya sendiri, setelah memerintah hanya tujuh hari. Rakyat sepeninggalnya memilih Tibni sebagai raja, sisanya memilih Omri sebagai penguasa. Pada akhirnya, Omri berhasil menggulingkan saingannya. Omri kini menjadi penguasa riil kota Tirza, yang lantas dinamakan dengan Samaria, memerintah selama sebelas tahun. $^{92}$

Kini bangsa Israel terdapat dua kerajaan: Israel dan Judah, yang terakhir memilih jalannya sendiri, sampai dikuasai oleh Omri (855-74) dengan ibukota baru, Samaria. Kerajaan Israel lebih luas dan lebih kaya dibanding Judah, karena lebih dekat dengan jalur dan terdiri dari negaranegara kota yang lebih makmur. Bisa dipahami, raja Judah menelan kepahitan menyesali lepasnya wilayah Israel dan menuduh kerajaan di

\footnotetext{
${ }^{88}$ Ibid., Book VIII, chapter 8: 212, 8.

${ }^{89}$ Ibid., Book VIII, chapter 11: 287, 358.

${ }^{90}$ Ibid., Book VIII, chapter 12: 304, 360.

${ }^{91}$ Ibid., Book VIII, chapter 12: 306-10, 361.

${ }^{92}$ Ibid., Book VIII, chapter 12: 311-3,
} 
utara melakukan penyimpangan (apostasy). Padahal, sebenarnya yang terjadi adalah pulihnya situasi seperti status qua antem sebelum terjadinya unifikasi kerajaan oleh Daud. Selama 50 tahun kerajaan Israel dan Judah berperang. Rehoboam berhasil menyelamatkan Yerusalem dari serangan Firaun Shisak yang berupaya meneguhkan kehadirannya di wilayah Kana'an. Pada masa pemerintahan Asa, kerajaan Israel berhasil mencapai Ramah, sejauh lima mil di utara kota Yerusalem. ${ }^{93}$

\section{Penutup}

Persoalan mengenai hubungan antar temuan-temuan ilmu pengetahuan dengan kata-kata kebenaran yang termuat dalam Kitab Suci, tidak ada gunanya jika seorang ahli teologi meragukan pendekatan pengetahuan. Interpretasi Alkitabiah semestinya tidak dimaksudkan untuk tafsiran yang tidak sesuai dengan maknanya. Dengan kata lain, tidak semestinya teks Alkitab "diperkosa" supaya cocok dengan ilmu pengetahuan modern. Penghormatan yang hakiki terhadap teks-teks kitab suci. Maka dari itu, biasanya tujuan studi Alkitab sebatas pada arah teologis, bukanlah memperlakukan teks kitab suci sebagai ensiklopedia bermacam-macam pengetahuan. Baru pada masa setelah abad pencerahan di Eropa, para sarjana mulai meneliti Alkitab dari perspektif historis. ${ }^{94}$

Penelitian-penelitian ilmiah masih belum sepakat mengenai asalusul bangsa Ibrani, tetapi tulisan-tulisan tentang sejarah Yudaisme banyak menyebut kelompok sosial yang disebut apiru, babiru atau bapiru, yakni kelompok orang yang tak terikat secara politis pada negara tertentu-yakni kelompok pengembara, atau tentara sewaan. Makna istilah ini mungkin saja terkait dengan kata Tbri (atau Ibrami). Namun, perlu dicatat bahwa mereka mewakili kelompok pinggiran di kawasan Mesopotamia yang berkaitan langsung dengan bangsa Ibrani (Israel

93 Raja Israel berhasil menyelamatkan kota dengan meminta bantuan Kerajaan Damaskus (bangsa Aramia), yang menyerang Israel dari belakang. Sejak itu, kerajaan Israel dipusingkan dengan rangkaian perang memperebutkan teritorial dengan Damaskus dan membiarkan Judah. Lihat Armstrong, Jerusalem, 58.

${ }^{94}$ Snell, Kebidupan di Timur Tengab Kuno, 9. 
kemudian) dan kisah penaklukkan Israel atas tanah Kana'an masih menjadi topik perdebatan.

Bahkan sampai pada masa penobatan Daud sebagai penguasa monarki di kota Yerusalem, dia justru mendirikan negara yang lebih multinasional, bertentangan dengan klaim tafsir ideologis modern Zionisme atas hak historis mereka di kawasan Palestina. Daud sendiri menggunakan pasukan pengawal dari bangsa Kreti dan Paleti yang berasal dari Pulau Kreta dan kawasan laut Tengah. Dengan demikian, penulis setuju dengan kritik keras seputar Yahwisasi sejarah di Palestina yang keterlaluan, dalam konteks ini Roger Garaudy. ${ }^{95}$ Satu-satunya sumber tentang mereka yang berasal dari bangsa yang dalam sejarah disebut Hapiru adalah dari sumber-sumber biblikal. Dari perkawinan Daud dengan salah seorang perempuan bangsa Hittite, dia mendapatkan anak laki-laki pewarisnya, bernama Sulaiman. Raja ini makin lebih memperluas sifat multinasional ciri negara yang didirikan.

Dapat disimpulkan juga bahwa bagian-bagian dari Alkitab (perjanjian lama) yang bernilai sejarah bukan sebatas ditafsirkan sebagai sejarah nasional bangsa Israel, melainkan tentang sejarah kerajaan Allah di dalam dunia ini. Meski mula-mula diperuntukkan oleh bangsa Israel pada abad ke-14 sampai ke-13 S.M., sehingga ia sesuai dengan alam pemikiran dari bangsa itu di masanya. Hal ini mencerminkan bagaimana umat Israel menjadi makmur dengan kecintaan mereka terhadap Allah, dan hancur bersama kemurkaan Allah manakala mereka menyimpang dari kehendak-Nya. Sebagaimana dalam lisan nabi Amos yang mencela tindak korupsi dan penindasan, semisal apa yang dilakukan oleh Jeroboam II dari Israel utara (783-742 S.M.). ${ }^{96}$

\section{Daftar Pustaka}

Alkitab. Jakarta: Percetakan Lembaga Alkitab Indonesia, cet. ke-6, 1996.

\footnotetext{
95 R. Garaudy, Zionis Sebuah Gerakan Kaeagamaan dan Politik (Jakarta: Gema Insani Press, 1993), 73-7.

${ }^{96}$ D.C. Mulder, Iman dan Ilmu Pengetahuan, (Jakarta: BPK Gunung Mulia, 1997), 24-5.
} 
The Holy Bible: New Revised Standard Version. Published by the Division of Christian Educaion of the National Council of Churches of Christ in USA. Michigans: Zondervan Publishing House, 1989.

Aitonam, S.O. (LAI). Forum Biblika: Jurnal Ilmiah Populer. Jakarta: Lembaga Alkitab Indonesia, 1998.

Albright, W.F. The Archaelogy of Palestine. Middlesex: Penguin Books, 1951.

Armstrong, Karen. Yerusalem: One City, Three Faiths. New York: Ballantine Books, 2005.

. The Great Transformation: the Beginning of Our Religious Traditions. New York: Anchor Book, 2006.

. In the Beginning: A New Interpretation of Genesis. London: Vintage, 2011.

Baker. David L. dan John J. Bimoson. Mengenal Arkeologi Alkitab. Jakarta: BPK Gunung Mulia, 2004.

Childe, V. Gordon. A Short Introduction to Archaeology. New York: Collier, 1962.

Doniger, Wendy. Merriam-Webster's Encyclopedia of World Religions. Massachussets: Merriam-Webster, Inc., 1999.

Eliade, Mircea. Sakral dan Profan. Yogyakarta: Fajar Pustaka Baru, 2002.

Free Joseph P. dan Howard F. Vos. Arkeologi dan Sejarah Alkitab. Malang: Yayasan Penerbit Gandum Mas, 2001.

Garaudy, R. Zionis Sebuah Gerakan Kaeagamaan dan Politik. Jakarta: Gema Insani Press, 1993.

Hayes. John H. dan Carl R. Holladay. Pedoman Penafsiran Alkitab. Jakarta: BPK Gunung Mulia, 1993.

Hinson, Davd F. Sejarah Israel pada Zaman Alkitab. Jakarta: BPK Gunung Mulia, 1993.

Josephus, Flavius. Jewish Antiquities. translated by William Whilston. Herfordshire: Wordswoth Classic, 2006. 
King, Philip J. dan Lawrence E. Stager. Kehidupan Orang Israel Alkitabiah, Jakarta: BPK Gunung Mulia, 2010.

Mulder, D.C. Iman dan Ilmu Pengetabuan. Jakarta: BPK Gunung Mulia, 1997.

Neusner, Jacob. The Way of Torah: an Introduction to Yudaisme. Belmont, Calif: Wadsworth, Inc., 1979.

Rogerson, John. Studi Perjanjian Lama bagi Pemula. Jakarta: BPK Gunung Mulia, 1993.

Snell, Daniel C. Kehidupan di Timur Tengah Kuno 3100-332 S.M. Jakarta: BPK Gunung Mulia, 2009. 